\title{
THE STUDY OF ANTIOXIDANTS TO EVALUATE THE HEALING EFFECTS OF PUNICA GRANATUM PEEL ON ACETIC ACID-INDUCED COLITIS IN CHARLES-FOSTER ALBINO RATS
}

\author{
ARPIT VERMA ${ }^{1}$, ANAND BHADKARIYA ${ }^{2}$, SUPRIYA SHARMA ${ }^{3}$, NIKITA TOSHI** \\ ${ }^{1}$ Department of Pharmacology, Government Medical College, Datia, Madhya Pradesh, India. ${ }^{2}$ Department of Pathology, Government Medical \\ College, Datia, Madhya Pradesh, India. ${ }^{3}$ Department of Pharmacology, Netaji Subhash Chandra Bose Medical College, Jabalpur, Madhya \\ Pradesh, India. ${ }^{4}$ Department of Psychiatry, Government Medical College, Datia, Madhya Pradesh, India. Email: drnikita.toshi@gmail.com
}

Received: 04 November 2021, Revised and Accepted: 15 December 2021

ABSTRACT

Objective: The study aims to analyze the effect of 50\% ethanolic extract of the dried Punica granatum peel (PGE) on the healing of acetic- acid-induced colitis in rats.

Methods: Colitis was induced in rats using 50\% acetic acid and then PGE extract was administered by oral route daily for 14 days to those rats. Optimal healing was observed by the administration of a $100 \mathrm{mg} / \mathrm{kg}$ dose of PGE extract. Effectiveness of the above-mentioned dosage of PGE on biochemical parameters namely- antioxidants-superoxide dismutase and reduced glutathione were studied on $18 \mathrm{~h}$ fasting rats on the $15^{\text {th }}$ day of the experiment.

Results: The results were suggestive of the healing properties of PGE extract by reduction of the inflammation and mucosal damage in the colon of those rats. The effect was established by the levels of antioxidants that indicate healing of the mucosal damage. The safety of extract was established by the effective administration of 10 times the therapeutic dose, that is, $1000 \mathrm{mg} / \mathrm{kg}$ dosage of the PGE extract with no noticeable adverse effects or side effects related to autonomic nervous system or central nervous system.

Conclusion: PGE extract was found to be effective in healing mucosal damage due to colitis by controlling the infection and reducing the inflammation.

Keywords: Ulcerative colitis, Punica granatum peel extract, Acetic acid, Sulfasalazine, Antioxidants.

(C) 2022 The Authors. Published by Innovare Academic Sciences Pvt Ltd. This is an open access article under the CC BY license (http://creativecommons.org/ licenses/by/4.0/) DOI: http://dx.doi.org/10.22159/ajpcr.2022v15i2.43895. Journal homepage: https://innovareacademics.in/journals/index.php/ajpcr

\section{INTRODUCTION}

Ulcerative colitis (UC) is a chronic, inflammatory illness of the colon which affects the innermost lining of the intestines. The condition leads to inflammation, sores or ulcers, and bleeding in the gastric mucosal lining. Symptoms include a progressive relaxing of the stool, abdominal cramps, rectal bleeding, and loss of appetite that result in nutrient deficiencies, weight loss, and anemia [1]. A combination of genetic, microbial, and environmental features that influence the normal intestinal microbiota is considered responsible to trigger a pathological immune response resulting in mucosal damage. Genetic and environmental factors are also thought to play some role; the exact cause is still not clear. Among the pathological findings associated with UC is an increase in certain inflammatory mediators, signs of oxidative stress, a deranged colonic milieu, abnormal glycosaminoglycan content of the mucosa, decreased oxidation of short-chain fatty acids, and augmented intestinal permeability [2,3]. Reactive oxygen species (ROS) mediated wound plays a significant part in the pathophysiology of UC. Chronic inflammation, infection, or immune imbalance increases the production of ROS and impairs antioxidant defenses, resulting in intestinal oxidative injury in UC patients [4].

Punica grantum plant commonly known as the pomegranate is an attractive shrub or small tree growing 6-10 m high with multiple spiny twigs, The edible fruit is a berry and is $5-12 \mathrm{~cm}$ in diameter with a rounded shape and thick reddish skin (peel). In the Indian subcontinent's ancient Ayurveda scheme of medicine, the pomegranate has extensively been used as a basis of traditional remedies being considered as a pharmacy in itself. It is used as an antiparasitic agent, hemostatic, antibacterial, antifungal, antiviral, and as a remedy for cut wounds, a gore tonic, an eyedrop and to heal ulcers. The peel of the fruit is used to luxury diarrhea, dysentery, and duodenal parasites. The astringent qualities of the flower juice, peel, and tree bay are considered valued for a variety of purposes, such as toning skin, firming up sagging breasts, and treating hemorrhoids. In south Anatolia, turkey, some persons employ the ashes of the fruit peel as protective against skin infection. The plant extract has been exposed to possess antiinflammatory activity, anticancer activity [5], and antispermatogenic effect. It isexceedingly valued for its neuroprotective property in stressinduced neurodegeneration like Alzheimer's disease [5]. It has an antiatherogenic effect and demonstrates hypoglycemic activity in diabetic rats.

The present study was undertaken to evaluate the healing effects of $50 \%$ ethanol extract of Punica granatum peel (PGE) in acetic acidinduced colitis in rats.

\section{METHODS}

\section{Animals}

Inbred Charles-Foster albino rats (160-180 g) and mice (25-30 g) of either sex were obtained with permission from the central animal house of the Institute of Medical Sciences, Banaras Hindu University, Varanasi. They remained reserved in the departmental animal house at $26 \pm 20^{\circ} \mathrm{C}$ and relative humidity $44-56 \%$, light and dark cycles of 10 and $14 \mathrm{~h}$, respectively, for 1 week before and during the duration of experiments. Animals were provided with a standard rodent pellet diet (PashuAahar, Ramnagar, and Varanasi) and water ad libitum. "Principles of laboratory animal care (NIH publication no. 82-23, revised 1985) rules were followed. Approval from the Official Animal Ethical Committee was taken before the initiation of experimental work (Notification no.: Dean/12-13/CAEC/10 dated 11.01.2013).

\section{Plant material and preparation of extract}

The whole plant of $P$. granatum was collected in the months of September-November from the Ayurvedic Gardens of Banaras Hindu 
University. The peel was dried in shade and blended to form a fine powder and used. 50\% ethanolic excerpt of PGE was prepared by adding $200 \mathrm{~g}$ of dried fine powder of PGE in $1000 \mathrm{ml}$ of ethanol $(500 \mathrm{ml})$ and distilled water $(500 \mathrm{ml})$ mixture. The mixture was shaken at regular intervals and the extract so obtained was filtered after a gap of 2 days. $\mathrm{PGE}$ so got each time remained mixed and later dried at $40^{\circ} \mathrm{C}$ in the incubator. The yield was about $20 \%\left(\mathrm{w} / \mathrm{w}\right.$ ). PGE stood stored at $-20^{\circ} \mathrm{C}$ until further use.

\section{Drug and chemicals}

Sulfasalazine (TAB. SALAZAR 500mg by Zydus Cadila), acetic acid, and all the other chemicals, and reagents that were used were of analytical grade.

\section{Chemicals}

\section{Estimation of protein}

a. Alkaline preparation - $50 \mathrm{ml}$ Alkaline reagent $+0.5 \mathrm{ml}$ of $4 \%$ Superoxide dismutase (SOD) Pot. Taratarate $+0.5 \mathrm{ml}$ of $2 \%$ copper sulphate. (Alkaline reagent $-2 \mathrm{~g}$ of sodium Bicarbonate $+100 \mathrm{ml}$ of $0.1 \mathrm{~N} \mathrm{NaOH}$ )

b. Phenol reagent $-5 \mathrm{ml}$ of phenol $+5 \mathrm{ml}$ of distilled water.

\section{Estimation of antioxidants}

SOD

a. Sodium pyrophosphate (Sigma) $-0.052 \mathrm{M}$ sodium pyrophosphate was prepared by adding $1.16 \mathrm{~g}$ in $50 \mathrm{ml}$ of distilled water and the $\mathrm{pH}$ was adjusted to 8.3

b. Phenazinemethosulphate (PMS) (Sigma) - $186 \mu$ mol of PMS prepared by adding $0.018 \mathrm{ml}$ of $100 \mathrm{mM}$ of PMS to $10 \mathrm{ml}$ of distilled water. 100 $\mathrm{mM}$ of PMS prepared by adding $0.306 \mathrm{~g}$ in $10 \mathrm{ml}$ of distilled water

c. Nitroblue Tetrazolium (NBT) (Sigma) - Prepared in a concentration of $300 \mu \mathrm{M}$ by dissolving $2.754 \mathrm{mg}$ of NBT in $10 \mathrm{ml}$ of distilled water

d. NADH (Sigma) - $780 \mu \mathrm{M}$ concentration of NADH was prepared by dissolving $11.1 \mathrm{mg}$ of in $20 \mathrm{ml}$ of distilled water.

Reduced glutathione (GSH)

a. $\quad 0.4 \mathrm{M}$ Tris buffer (Sigma) - Prepared by dissolving $4.84 \mathrm{~g}$ of Tris in a small amount of distilled water and adding $10 \mathrm{ml}$ of $0.2 \mathrm{M}$ Disodium Edetate (EDTA) and making up to $100 \mathrm{ml}$ with distilled water. Adjust the $\mathrm{pH}$ to 8.9 with $1 \mathrm{~N} \mathrm{HCl}$

b. $0.2 \mathrm{M}$ EDTA - 7.4 g of the sodium salt of EDTA (E. Merck) was dissolved in $100 \mathrm{ml}$ of distilled water

c. $\quad 0.02 \mathrm{M}$ EDTA - Take $10 \mathrm{ml}$ of $0.2 \mathrm{M}$ EDTA and makeup to $100 \mathrm{ml}$ with distilled water

d. $0.1 \mathrm{M}$ DTNB - Dissolve $99 \mathrm{mg}$ of DTNB (Hi-Media) in $25 \mathrm{ml}$ of absolute methanol

e. $50 \%$ Trichloroacetic acid (TCA) - 50\% solution was prepared by dissolving $10 \mathrm{~g}$ TCA in $20 \mathrm{ml}$ of distilled water

f. GSH standard: Standard GSH was used for the estimation of the standard curve.

\section{Induction of colitis and treatment protocol}

Experimental colitis was produced by intracolonic administration of acetic acid (10\%, $0.20 \mathrm{ml} / 100 \mathrm{~g}$ rat) given per rectally [6]. A doseresponse study was first undertaken with $50 \%$ ethanol extract of PGE (50, 100 and $200 \mathrm{mg} / \mathrm{kg}$ ) when given orally for a period of 14 days after the induction of UC with acetic acid and on the $15^{\text {th }}$ day of the experiment, the healing effect was studied using biochemical parameters, that is, antioxidants -SOD and reduced GSH on the $15^{\text {th }}$ day of the experiment in $18 \mathrm{~h}$ fasting rats. The animals were sacrificed on the $15^{\text {th }}$ day after intra-colonic administration of whichever normal saline (negative control) or acetic acid (control) and afterward treatments with PGE excerpt (test extract, $100 \mathrm{mg} / \mathrm{kg}$ ) then sulfasalazine (positive control, $100 \mathrm{mg} / \mathrm{kg}$ ) [7] in acetic acid-induced colitis rats. PGE and standard UC protective drug, sulfasalazine postponement was prepared in $0.5 \%$ carboxymethyl cellulose (CMC) and administered orally, once daily in the volume of $1 \mathrm{ml} / 100 \mathrm{~g}$ rat for 14 days after the induction of colitis. The consequences of the acetic acid group were compared with a normal saline group while the treatment groups were compared with the acetic acid group.

\section{Biochemical estimations}

\section{Estimation of protein}

To estimate the protein content in the colonic mucosal homogenate, $95 \%$ ethanol was added to $0.1 \mathrm{ml}$ of colonic mucosal homogenate $(100 \mathrm{mg} / \mathrm{ml})$, and was then centrifuged at $3000 \mathrm{rpm}$ for exactly $5 \mathrm{~min}$. The hurried so obtained was dissolved in $1 \mathrm{ml}$ of $0.1 \mathrm{~N} \mathrm{NaOH} .0 .4 \mathrm{ml}$ of the above example was taken in another test tube. $4 \mathrm{ml}$ of alkaline reagent was then added to this test tube and kept for $10 \mathrm{~min}$. Then, $0.4 \mathrm{ml}$ of the phenol substance was added and again $10 \mathrm{~min}$ were allowed for color development. The absorbency was measured at $610 \mathrm{~nm}$ spectrophotometrically against blank prepared using distilled water. The protein content was estimated from the standard curve prepared with bovine albumin and has expressed as mg/g wet tissue.

\section{Estimation of antioxidants}

SOD

SOD was estimated by following the procedure of Kakkar and associates (1984). N-butyl alcohol was used to measure the inhibition of reduction of NBT to blue colored formazan in presence of PMS and NADH at $560 \mathrm{~nm}$. To $0.4 \mathrm{ml}$ of the homogenate add $1.2 \mathrm{ml}$ of sodium pyrophosphate buffer (pH 8.3, $0.052 \mathrm{M}$ ), $0.1 \mathrm{ml}$ of $186 \mu \mathrm{M}$ of PMS, $0.3 \mathrm{ml}$ $300 \mu \mathrm{M}$ nitrobluetetrazolium, and $0.8 \mathrm{ml}$ of distilled water to prepare a volume up to $3 \mathrm{ml}$ including $0.2 \mathrm{ml}$ of $\mathrm{NADH}(780 \mu \mathrm{M})$. NADH was used to initiate the reaction. After incubation at $30^{\circ} \mathrm{C}$ for $60 \mathrm{~s}$, the reaction remained stopped by the adding of $1.0 \mathrm{ml}$ of glacial acetic acid. $4.0 \mathrm{ml}$ of n-butanol was added to the reaction mixture which was then mixed thoroughly after stirring well. The mixture was allowable to stand for $10 \mathrm{~min}$, centrifuged and the butanol layer was taken out. The color intensity of the chromogen in the butanol was measured at $560 \mathrm{~nm}$ in a spectrophotometer against butanol. Control was selected to be a solution that was free of any enzymes. One unit of enzyme action is defined as enzyme concentration required inhibiting the optical density at $560 \mathrm{~nm}$ of chromogen protection by $50 \%$ in one min under the assay conditions, and the results have been expressed as units (U) of SOD activity/g wet tissue.

\section{Reduced GSH}

About $0.5 \mathrm{ml}$ of homogenate was mixed with $0.4 \mathrm{ml}$ of distilled water and $0.1 \mathrm{ml}$ of $50 \%$ TCA. The tubes were shaken intermittently for 10$15 \mathrm{~min}$ and centrifuged for $15 \mathrm{~min}$ at $3000 \mathrm{RPM}$. $0.6 \mathrm{ml}$ of supernatant was mixed with $0.8 \mathrm{ml}$ of $0.4 \mathrm{M}$ Tris buffer and $0.02 \mathrm{ml}$ of DTNB and the example was shaken. The absorbance was read within 5 min of the adding of DTNB at $412 \mathrm{~nm}$ against a reagent blank with no homogenate. The results were expressed as nmol/g-wet tissue and were calculated from the standard curve prepared using standard GSH.

\section{Statistical analysis}

Statistical comparison was performed using either unpaired " $t$ " test or one-way analysis of variance and for multiple comparisons versus control group was done by Dunnett's test. All statistical analysis was did using SPSS statistical version 16.0 software package (SPSS $®$ Inc., USA). $\mathrm{p}<0.05$ were considered statistically significant.

\section{RESULTS}

The effects of PGE extract (test extract, $100 \mathrm{mg} / \mathrm{kg}$ ) and sulfasalazine (positive control, $100 \mathrm{mg} / \mathrm{kg}$ ) on biochemical paradigms related to the inflammatory process and healing were estimated in mucosal incubates following induction of colitis by acetic acid. Antioxidant enzymes play an important role in healing and therefore levels of antioxidants such as SOD and reduced GSH were estimated in colonic mucosal homogenates from the normal, AA-treated, and extracts treated AA-induced colitis.

\section{Effect on antioxidants- SOD and GSH}

AA-treated animals showed a significant decrease in both SOD and GSH levels in the colonic mucosal incubates when expressed either as per g wet tissue weight or per mg protein compared to normal untreated rats. PGE ( $100 \mathrm{mg} / \mathrm{kg})$ and SS $(100 \mathrm{mg} / \mathrm{kg})$ when given for 14 days after AA-induction of colitis reversed the above change both in SOD and GSH levels near to NS group (Table 1 and Fig. 1). 
Table 1: Effects of PGE, and SS action on AA-induced changes in free radicals (lipid peroxidation and nitric oxide) and antioxidants (superoxide dismutase and glutathione) in AA-induced ulcerative colitis in rat's colon

\begin{tabular}{|c|c|c|c|c|c|}
\hline \multirow{3}{*}{$\begin{array}{l}\text { Oral treatment }(\mathrm{mg} / \mathrm{kg} \text {, } \\
\mathrm{OD} \times 14 \text { days })\end{array}$} & \multirow{3}{*}{$\begin{array}{l}\text { Protein } \\
\mathrm{mg} / \mathrm{g} \text { wet tissue }\end{array}$} & \multicolumn{4}{|l|}{ Anti-oxidants } \\
\hline & & \multicolumn{2}{|l|}{ SOD } & \multicolumn{2}{|l|}{ GSH } \\
\hline & & IU/g wet tissue & IU/mg protein & nmol/g wet tissue & nmol/mg protein \\
\hline NS+CMC 1\% & $57.0 \pm 3.62$ & $22.1 \pm 1.83$ & $0.37 \pm 0.05$ & $1547.1 \pm 152.6$ & $27.6 \pm 2.75$ \\
\hline $\mathrm{AA}+\mathrm{CMC} 1 \%$ & $51.2 \pm 2.98$ & $8.3^{* * *} \pm 1.3$ & $0.17^{* * *} \pm 0.02$ & $775.4^{* *} \pm 39.6$ & $15.4^{* *} \pm 1.3$ \\
\hline AA+PGE $100 \%$ & $66.9 \mathrm{c} \pm 2.03$ & $21.5 \mathrm{c} \pm 1.96$ & $0.32 \mathrm{~b} \pm 0.03$ & $1800.3 \mathrm{c} \pm 197.46$ & $27.0 \mathrm{~b} \pm 2.99$ \\
\hline $\mathrm{AA}+\mathrm{SS} 100 \%$ & $65.3 b \pm 1.83$ & $19.8 \mathrm{c} \pm 1.14$ & $0.32 b \pm 0.01$ & $1944.7 c \pm 98.93$ & $30.0 \mathrm{c} \pm 2.17$ \\
\hline
\end{tabular}

Results are mean \pm SEM of 6 rats in each group. ${ }^{* *}<0.01,{ }^{* * *}<0.001$ compared to respective NS group (unpaired " $\mathrm{t}$ " test), ${ }^{\mathrm{b}}<0.01,{ }^{\mathrm{c}}<0.001$, compared to respective AA group (Statistical analysis was done by one way analysis of variance followed by Dunnett's test for multiple comparisons), CMC: Carboxymethyl cellulose, SOD: Superoxide dismutase, GSH: Glutathione, PGE: Punica granatum peel

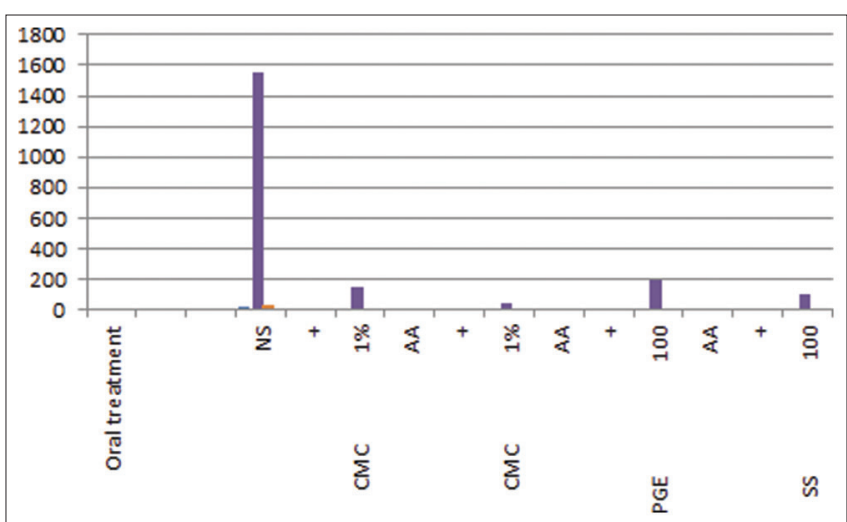

Fig. 1: The effects of Punica granatum peel, and SS treatment on AA-induced changes in antioxidants (superoxide dismutase and glutathione in rat's colonic mucosa)

The results of the present study with the PGE extract (test extract, $100 \mathrm{mg} / \mathrm{kg}$ ) and sulfasalazine (positive control, $100 \mathrm{mg} / \mathrm{kg}$ ) on various physical and biochemical parameters of colonic damage and inflammation induced by AA do indicate the effective healing effects of PGE.

\section{DISCUSSION}

Acetic acid-induced colitis has been reported to look like human inflammatory bowel disease in footings of prolonged colonic inflammation and serves as a useful model to investigate the role of free radicals and antioxidants in the pathophysiology of colitis [8,9]. Our results with intracolonic management of acetic acid showed an increase in inflammation and ulceration in the mucosa of rat's colon. Estimation of antioxidants such as SOD and reduced GSH in colonic mucosal tissues has also been relevant because these antioxidants hasten the process of healing by destroying the free radicals. The significant alteration in the antioxidant profile may be attributed to impairing healing in immunocompromised rats. Our studies on the SOD, and GSH status revealed that PGE possessed significant antioxidant activity which would help to prevent oxidative damage and promote the healing process and its effect was comparable with the sulfasalazine-treated group. The above effects may be attributed to the anti-inflammatory, antinociceptive and antiulcer properties of PGE. The presence of anti-inflammatory activity in PGE may be attributed to other pharmacologically active constituents such as ellagic acid, ellagitannins, punicic acid flavonoids, anthocyanidins, anthocyanins, and estrogenic flavonols and flavones isolated earlier [10,11]. Flavonoids are most commonly known for their antioxidant activity. Thus, PGE could have a potential role in the therapy of various inflammatory conditions including UC.

\section{CONCLUSION}

The results of the present study revealed that $50 \%$ ethanolic extracts of PGE have significant healing activity in both AA-induced colitis rats.
Antioxidants and colonic microorganisms play an important role in tissue injury and healing which were affected in AA-induced colitis, and their reversal by PGE, do suggest a possible role of P. granatum in the treatment of colitis which could be due to their promotion effect on antioxidant activity. Further, PGE seemed to be safe and did not produce any lethal effect.

\section{ACKNOWLEDGMENT}

All the authors express their sincere thanks to the Department of Pharmacology, Faculty of Medicine, Institute of Medical Sciences, Banaras Hindu University, Varanasi, India, for providing the best facilities for the research work.

\section{AUTHOR'S CONTRIBUTION}

Concept, Design, and Data collection was done by Dr. Arpit Verma. Data analysis and interpretation were done by Dr. Anand Bhadkariya. Drafting was done by Dr. Supriya Sharma. Critical revision and final approval of the version to be published were done by Dr. Arpit Verma and Dr. Nikita Toshi.

\section{CONFLICT OF INTEREST}

We declare that we have no conflict of interest.

\section{SOURCE OF FUNDING}

None.

\section{REFERENCES}

1. Kathleen A, Jurenka JS. Inflammatory bowel disease Part I: Ulcerative colitis pathophysiology and conventional and alternative treatment options. Altern Med Rev 2003;8:247-83.

2. Benson JM, Shepherd DM. Aryl hydrocarbon receptor activation by TCDD reduces inflammation associated with Crohn's disease. Toxicol Sci 2010;120:68-78.

3. Molodecky NA, Kaplan GG. Environmental risk factors for inflammatory bowel disease. Gastroenterol Hepatol 2010;6:339-46.

4. Khor B, Gardet A, Xavier RJ. Genetics and pathogenesis of inflammatory bowel disease. Nature 2011;474:307-17.

5. Akhlaghi M, Band B. Mechanisms of flavonoid protection against myocardial ischemia-reperfusion injury. $\mathrm{J}$ Mol Cell Cardiol 2009;46:309-17.

6. Gautam MK, Goel S, Ghatule RR, Singh A, Nath G, Goel RK, et al. Curative effect of Terminalia chebula extract on acetic acid-induced experimental colitis: Role of antioxidants, free radicals and acute inflammatory marker. Inflammopharmacol 2012;21:377-83.

7. Wiegand I, Hilpert K, Hancock RE. Agar and broth dilution methods to determine the minimal inhibitory concentration (MIC) of antimicrobial substances. Nat Protoc 2008;3:163-75.

8. Tahan G, Aytac E, Aytekin H, Gunduz F, Dogusoy G, Aydin S, et al. Vitamin $\mathrm{E}$ has a dual effect of anti-inflammatory and ulcerative colitis in rats. Can J Surg 2011;54:333-8.

9. Keshavarzian A, Banan A, Farhadi A, Komanduri S, Mutlu E, Zhang Y, et al. Increases in free radicals and cytoskeletal protein oxidation and nitration in the colon of patients with inflammatory bowel disease. Gut 2003;52:720-8. 
10. Lansky EP, Newman RA. Punicagranatum and its potential for prevention and treatment of inflammation and cancer. J Ethnopharmacol 2007;109:177-206
11. Pirbalouti AG, Koohpayeh A, Karimi I. The wound healing activity of flower extracts of Punicagranatum and Achilleakellalensis in wistar rats. Actapolonia Pharm Drug Res 2010;67:107-10. 